\title{
Iron intake and its association with iron-deficiency anemia in agricultural workers' families from the Zona da Mata of Pernambuco, Brazil ${ }^{1}$
}

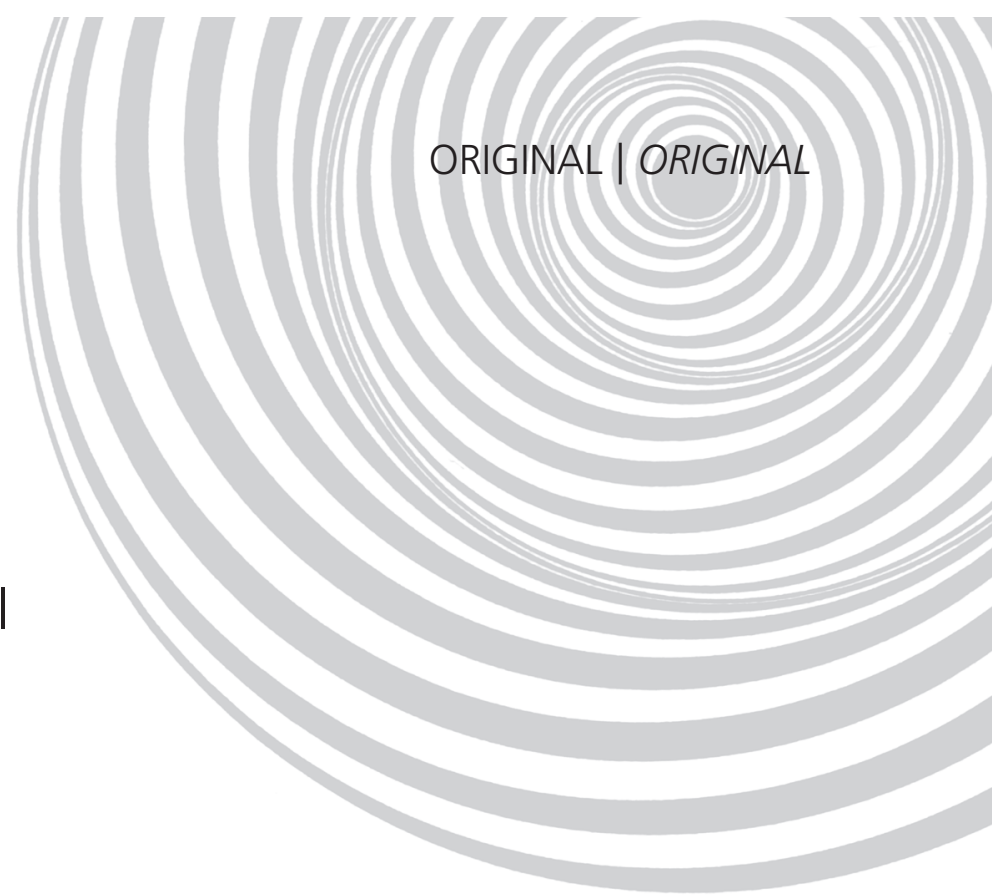

\author{
Consumo de ferro e sua associação com a \\ anemia ferropriva nas famílias de \\ trabalhadores rurais da Zona da
}

Mata de Pernambuco, Brasil

Débora Silva CAVALCANTI²

Priscila Nunes de VASCONCELOS²

Vanessa Messias MUNIZ2

Natália Fernandes dos SANTOS 3

Mônica Maria OSÓRIO²

A B S T R A C T

\section{Objective}

To verify the association between dietary iron intake and the occurrence of iron-deficiency anemia in agricultural workers' families from the municipality of Gameleira in the state of Pernambuco, Brazil.

\section{Methods}

The study population consisted of 46 harvesters' families, consisting of 225 individuals. The food intake of each individual was recorded on three different days by directly weighing the foods consumed. Hemoglobin was determined by fingerstick (HemoCue). This research used the probability of adequacy method to assess iron intake and the paired $t$ test for comparing groups. The Spearman Mann-Whitney test estimated associations between the dietary variables and anemia.

1 Article based on the master's thesis of the DS CAVALCANTI intiled "Consumo de ferro dietético e sua associação com a anemia

ferropriva nas familias de trabalhadores rurais do Nordeste do Brasil". Universidade Federal de Pernambuco; 2013.

2 Universidade Federal de Pernambuco, Centro de Ciências da Saúde, Programa de Pós-Graduação em Nutrição. Av. Prof. Moraes Rego, 1235, Cidade Universitária, 50670-901, Recife, PE, Brasil. Correspondência para/Correspondence to: DS CAVALCANTI. E-mail:<deborasec@gmail.com>.

3 Universidade Federal de Pernambuco, Centro de Ciências da Saúde, Curso de Nutrição. Recife, PE, Brasil. 


\section{Results}

The prevalence of anemia was high in all ages groups and highest $(67.6 \%)$ in children aged $<5$ years with a mean hemoglobin of $10.37 \mathrm{~g} / \mathrm{dL}( \pm 1.30 \mathrm{~g} / \mathrm{dL})$. Children aged $<5$ years had low percentage of iron intake adequacy (53.1\%). Most of them consumed diets with low iron bioavailability (47.5\%). Associations between the occurrence of anemia and dietary variables were significant for total iron (heme and nonheme), its bioavailabilities, and general meat intake.

\section{Conclusion}

Inadequate dietary iron intake and inadequate intake of factors that facilitate iron absorption can be considered decisive for the occurrence of iron-deficiency anemia. Food insecurity occurs between family members, with some members being favored over others with regard to the intake of good dietary iron sources.

Indexing terms: Iron deficiency anemia. Family. Food consumption. Iron deficiency. Iron dietary.

\section{R E S U M O}

\section{Objetivo}

Verificar a associação entre o consumo de ferro dietético e a ocorrência da anemia ferropriva em famílias de trabalhadores rurais do município de Gameleira, Pernambuco.

\section{Métodos}

A população foi composta por 46 familias de trabalhadores de cana-de-açúcar, totalizando 225 indivíduos. Para cada indivíduo, foram realizados três inquéritos alimentares pelo método de registro alimentar por pesagem direta dos alimentos e dosagem de hemoglobina por meio do equipamento Hemocue. Utilizou-se o método da adequação aparente para avaliar a ingestão de ferro, e o teste t pareado na comparação entre grupos de indivíduos. Para estimar associações entre variáveis dietéticas e anemia, foi utilizado o teste de Mann-Whitney.

\section{Resultados}

A prevalência de anemia foi elevada em todas as faixas etárias, sendo maior $(67,6 \%)$ no grupo de crianças com menos de 5 anos de idade, com média de hemoglobina de 10,37 g/dL ( $\pm 1,30 \mathrm{~g} / \mathrm{dL})$. Na análise da adequação aparente, as crianças menores de 5 anos apresentaram baixo percentual de adequação (53,1\%). A maioria delas apresentou um percentual elevado de dieta com baixa biodisponibilidade de ferro $(47,5 \%)$. As associações entre a ocorrência de anemia e as variáveis dietéticas mostraram-se estatisticamente significantes para ferro total (heme e não heme), suas biodisponibilidades e consumo de carnes em geral.

\section{Conclusão}

A inadequação do consumo de ferro dietético e dos fatores facilitadores da sua absorção pode ser considerada determinante para a ocorrência da anemia ferropriva. As famílias vivenciam insegurança alimentar intrafamiliar, com discriminação do consumo de alimentos fontes de ferro entre seus membros.

Termos de indexação: Anemia ferropriva. Família. Consumo de alimentos. Deficiência de ferro. Ferro na dieta.

\section{INTRODUCTION}

Iron-deficiency anemia is one of the most prevalent nutritional deficiencies that translates as an important indicator of malnutrition and poor health, affecting one out of every four individuals, that is, $24.8 \%$ of the world population. Although the most affected groups are children, women of childbearing age, and low-income families, all individuals regardless of social stratum are susceptible to this deficiency ${ }^{1,2}$.
Food and nutrition security regards ensuring and facilitating food access to the population and making sure that individuals have healthy food habits $^{3}$ in order to promote health and general wellbeing. Thus, planned strategies are needed in the regions with the greatest social and economic inequalities because their inhabitants are even more prone to nutrition disorders.

In this context, special attention should be given to populations that may be at high risk of nutritional deficiencies, such as the agricultural 
workers' families from the municipality of Gameleira in Pernambuco, one of the municipalities with the lowest Human Development Index (HDI) in the Brazilian Northeast. These families live in marginalized areas and are usually paid low production-based salaries for harvesting sugarcane $e^{4}$. Hence, the general situation of this population gets worse off season, when they face financial instability and higher food and nutrition insecurity.

A successful fight against nutritional deficiencies is closely related to the ability to intervene on its determinants 5 . In the understanding of iron-deficiency anemia as a nutritional deficiency of multifactorial etiology, it is important to consider dietary factors as one of its main determinants. Roughly $90 \%$ of anemia cases involve iron deficiency: either the iron intake is low, or its bioavailability is low'. However, the number of population-based studies on irondeficiency anemia that investigate inadequate iron intake as the determinant of anemia during different life phases is still small.

In this sense, it is important to verify the association between dietary iron intake and the presence of anemia in families of sugarcane harvesters to determine the severity of the problem and the life phases where the nutritional risk is greatest, and to provide information for the creation and implementation of effective food and nutrition security strategies.

\section{METHODS}

This is an observational, analytical, crosssectional study of a limited population of neighboring residents of cane sugar mills. The sample consists of 46 families of sugarcane harvesters from the rural area of the municipality of Gameleira, in the State of Pernambuco in the Brazilian Northeast. These families represent a population composed of 225 individuals where 40 are less than 5 years of age; 50 are 5 to 11 years of age; 15 are 12 to 14 years of age; 50 are females aged $\geq 15$ years; 5 are pregnant women aged $\geq 15$ years; and 65 are males aged $\geq 15$ years.

The study lasted from February to April 2007, a period between sugarcane harvests. Data were collected by a team of dieticians consisting of six researchers and a field supervisor previously trained by the Department of Nutrition of the Universidade Federal de Pernambuco (UFPE).

Individual food intake was determined by directly weighing the foods consumed by an individual during the day for three nonconsecutive days, including a weekend day. For this purpose, a researcher would stay at an individual's home during the entire day, weighing or measuring and recording the solid and liquid foods consumed.

The solid foods consumed by each family member during each meal were weighed in all homes. Each food/preparation was weighed individually before being consumed using the utensils in which the foods were served and zeroing the scale before the addition of each food. A portable electronic scale with a capacity of $5 \mathrm{~kg}$ and accuracy of $1 \mathrm{~g}$ was used for weighing the solid foods. The liquid foods were measured by $100 \mathrm{~mL}$ and $500 \mathrm{~mL}$ graduated cylinders with $1 \mathrm{~mL}$ and $10 \mathrm{~mL}$ increments, respectively. The foods not consumed by each individual were weighed/ measured and subtracted from the initial weight.

The food weights were entered into and analyzed by the software DietPro 5.1i Profissional (Agromídia Software, Minas Gerais, Brazil). This software analyzes macro- and micronutrients. The breast milk consumed by some children was determined by the software Virtual Nutri (Department of Nutrition, School of Public Health, Universidade de São Paulo, São Paulo, Brazil), according to breastfeeding frequency and volume according to the child's age.

Dietary iron intake was assessed according to the food intake of each family member, quantifying total iron, heme iron, and nonheme iron consumed daily separately. Then the mean intake was calculated from the three study days. Heme iron was given by foods of animal origin 
(meats in general, including organ meats) and nonheme iron by foods of plant origin (grains, legumes, and vegetables). For the foods of plant origin, $100 \%$ of the iron was considered nonheme; for those of animal origin, $60 \%$ of the iron was considered nonheme ${ }^{6}$.

The method used for assessing individual dietary iron bioavailability was developed by Monsen \& Balintfy ${ }^{6}$ and Monsen et al. ${ }^{7}$, who consider the general meat and ascorbic acid intakes and characterize dietary iron as of low, medium, or high bioavailability. Vitolo \& Borlolini ${ }^{8}$ presented the data for this method considering cooked meat amounts, a method repeated by the present study. Diets having low iron bioavailability were those with less than $23 \mathrm{~g}$ of meat and less than $75 \mathrm{mg}$ of vitamin C; diets with medium iron bioavailability were those with $23 \mathrm{~g}$ to $70 \mathrm{~g}$ of meat and less than $25 \mathrm{mg}$ of vitamin C; diets with high iron bioavailability were those with more than $70 \mathrm{~g}$ of meat and more than $25 \mathrm{mg}$ of vitamin C.

The algorithm of Monsen \& Balintfly ${ }^{6}$ algorithm was used for calculating the percentage of nonheme iron bioavailable in the diet. This algorithm considers Stimulating Factors (SF) for iron absorption, specifically meats and vitamin $\mathrm{C}$ present in meals. One $\mathrm{SF}=1 \mathrm{mg}$ of ascorbic acid or $1 \mathrm{~g}$ of cooked meat.

The absorption of dietary nonheme iron may vary from $3 \%$ (no SF) to $8 \%(\mathrm{SF} \geq 75)$ and when the SF sum $<75$, the percentage of absorption corresponds to $3+8.93 \log ((\mathrm{SF}+100) /$ 100). Twenty-three percent of the heme iron was estimated to be bioavailable, given that it is not affected by other dietary nutrients. In the present study, the absorption percentage of the heme and nonheme iron of each daily food record was calculated for the complete diet. The study also used as reference an individual iron reserve of $500 \mathrm{mg}$ since the iron reserves of the study individuals are unknown 6 .

Hemoglobin level was determined on the first home visit by fingerstick, read by the device Hemocue (HemoCue Inc., Laguna Hills, United States of America). The cut-off points for iron- deficiency anemia used were those provided by the World Health Organization (WHO) according to gender and age ${ }^{1}$ as follows: $\mathrm{Hb}<11 \mathrm{~g} / \mathrm{dL}$ for children aged 6 to 59 months and pregnant women; $\mathrm{Hb}<11.5 \mathrm{~g} / \mathrm{dL}$ for children aged 5 to 11 years; $\mathrm{Hb}<12 \mathrm{~g} / \mathrm{dL}$ for adolescents aged 12 to 14 years and women aged $\geq 15$ years; and $\mathrm{Hb}<13 \mathrm{~g} / \mathrm{dL}$ for men aged $\geq 15$ years.

The database was constructed in the software Epi Info version 6.04 (Centers for Disease Control and Prevention-CDC, Atlanta, United States of America) and Statistical Package for the Social Sciences (SPSS) version 13.0, which also performed the statistical analyses. The significance level $\alpha$ for all tests was set at $5 \%$.

The Mann-Whitney test investigated possible associations between the dependent variable iron-deficiency anemia and the independent variables total iron, including its subtypes and bioavailability, vitamin $C$, and meats in the diets of all individuals. The Mann-Whitney test was used because the sample data was asymmetrically distributed.

Intakes of iron and its subgroups (mg) were first checked by adjusting the normal distribution curve of these nutrients for each age group using the nonparametric Kolmogorov-Smirnov test. The study used the mean total iron intake, mean heme iron intake, and mean nonheme iron intake given that the distribution of this mineral was symmetric in all life phases.

The apparent adequacy method assessed whether the iron intakes met the individuals' requirements: the intakes were analyzed according to life phase and some life phases were represented by fewer than 30 individuals $^{9}$. This is a statistical approach that compares the difference between habitual intake and Estimated Average Requirement (EAR), and considers the varying requirements and intrapersonal daily variation. The method refers to a Z-score that indicates the probability of dietary adequacy.

The requirement variability was estimated by considering a Variation Coefficient (VC) of 10\% for the nutrient iron. Intrapersonal variation was 
given by food intake studies of American populations ${ }^{9}$, since Brazilian studies do not include this information.

For children aged one to three years, the present study used the intrapersonal variation for children aged four to eight years, since the required datum for children under four years of age was not available in the literature. Breastfed children under one year of age were excluded from the food intake analysis because there is not intrapersonal variation for the apparent adequacy method and because this age group has very specific nutritional requirements.

The Z-score area was given by the normal distribution table, which indicated the probability of adequate iron intake. The reliability level was set at $p \geq 0.70$.

The Z-scores verified the difference between the apparent adequacy of dietary iron intake of each age group. Two groups were compared at a time: men $\geq 15$ years $x$ women $\geq 15$ years; men $\geq 15$ years $x$ children $<5$ years; men $\geq 15$ years $x$ children/adolescents 5 - 14 years; women $\geq 15$ years $x$ children $<5$ years; women $\geq 15$ years $x$ children/ adolescents 5-14 years; children $<5$ years $x$ children/adolescents 5-14 years. Children and adolescents were analyzed together because the number of adolescents was not enough for the said analysis in the study families.

In families with more than one individual per group, the mean Z-score was used. Given the heterogeneous composition of the families, some families were excluded from some analyses because they did not have individuals from one of the paired groups.

The Z-score differences between the groups in each family were calculated. Considering a two-tailed distribution, the paired Student's $t$ test compared the Z-scores of the groups of all families to investigate whether significant differences occurred.

The present study was approved by the Research Ethics Committee of UFPE under Protocol (Certificado de Apresentação para Apre- ciação Ética - CAAE) number 1460.0.172.000-05 and met the regulations for human research given by Resolution $n^{\circ} 196 / 96$ from the National Health Council. Individuals diagnosed as anemic received ferrous sulfate supplements for six months and were advised to visit a health care facility.

\section{RESULTS}

The groups most affected by iron-deficiency anemia were children aged $<5$ years and pregnant women, with rates of $67.6 \%$ (95\% Confidence Interval $-95 \% \mathrm{Cl}=51.6-83.6)$ and $60 \%(95 \% \mathrm{Cl}=9.6-110.3)$, respectively. On the other hand, men aged $\geq 15$ years are the least affected, with a rate of $20.3 \%(95 \% \mathrm{Cl}=13.0-27.6)$. Additionally, the pregnant women had the lowest percentage $(20.0 \%)$ of apparent iron intake adequacy, followed by children aged $<5$ years $(53.1 \%)$. Men aged $\geq 15$ years presented adequate iron intake and the highest mean iron intake (21.66 $\pm 7.87 \mathrm{mg}$ ) (Table 1).

The data in Table 2 shows that anemia was inversely associated with total iron, iron subtypes (heme and nonheme iron), its bioavailabilities, and meat intake. Despite the significant association between anemia and vitamin $C$, the association was directly proportional to vitamin $\mathrm{C}$ intake.

The apparent iron intakes of the study groups differed significantly for most paired groups, except for women aged $\geq 15$ years and children/adolescents aged 5 to 14 years $(p=0.86)$. Men aged $\geq 15$ years consumed significantly more iron than the other groups, and the difference was even greater when they were compared with the iron intake of children aged $<5$ years $(t=7.24$; $p<0.001)$. Generally, the apparent iron intakes of the children aged $<5$ years is always worse than the apparent iron intakes of all other groups (Table 3).

Figure 1 shows that most of the total iron consumed by all groups is nonheme. The mean nonheme iron intake of children aged $<5$ years is 23 times their mean heme iron intake, the greatest 
Table 1. Anemia rate, mean hemoglobin, mean iron intake, and apparent adequacy of iron intake of sugarcane harvesters' families by age group. Gameleira (PE), Brazil, 2007.

\begin{tabular}{|c|c|c|c|c|c|c|c|c|}
\hline \multirow{2}{*}{ Age group } & \multirow{2}{*}{$\mathrm{N}$} & \multicolumn{2}{|c|}{ Anemia } & \multicolumn{2}{|c|}{$\mathrm{Hb}(\mathrm{g} / \mathrm{dL})$} & \multicolumn{2}{|c|}{ Iron (mg) } & \multirow{2}{*}{$\begin{array}{c}\text { Apparent } \\
\text { adequacy (\%) }\end{array}$} \\
\hline & & $\%$ & $95 \% \mathrm{Cl}$ & M & SD & M & SD & \\
\hline$<5$ years & 40 & 67.6 & $(51.6-83.6)$ & 10.37 & \pm 1.30 & 5.03 & $\pm \quad 3.78$ & $53.1^{b}$ \\
\hline 5 a 11 years & 50 & 44.0 & (39.5-48.5) & 11.57 & $\pm \quad 1.37$ & 9.40 & $\pm \quad 3.19$ & 82.0 \\
\hline 12 a 14 years & 15 & 53.3 & $(30.4-76.2)$ & 11.95 & \pm 1.10 & 12.39 & $\pm \quad 3.84$ & 86.7 \\
\hline$\geq 15$ years (women) & 50 & 38.8 & $(33.2-44.4)$ & 12.28 & \pm 1.18 & 14.57 & $\pm \quad 5.65$ & 84.0 \\
\hline$\geq 15$ years (pregnant $^{a}$ ) & 05 & 60.0 & $(9.6-110.3)$ & 11.26 & \pm 1.19 & 16.55 & \pm 10.78 & 20.0 \\
\hline$\geq 15$ years (men) & 65 & 20.3 & $(13.0-27.6)$ & 13.98 & \pm 1.24 & 21.66 & $\pm \quad 7.87$ & 100.0 \\
\hline
\end{tabular}

Note: aAll pregnant women were aged 15 years or more; ${ }^{\text {b}}$ The apparent adequacy was not calculated for children under 12 months of age. 95\% Cl: 95\% Confidence Interval; M: Mean; SD: Standard Deviation.

Table 2. Distribution of dietary heme iron, nonheme iron, total iron, respective bioavailabilities, vitamin $C$, and meats according to anemia in sugarcane harvesters' families. Gameleira (PE), Brazil, 2007.

\begin{tabular}{lrrr}
\hline \multirow{2}{*}{ Variables } & \multicolumn{2}{c}{ Anemia } & \multirow{2}{*}{$p$} \\
\cline { 2 - 3 } & \multicolumn{1}{c}{ Yes } & No & 0.009 \\
Heme iron & $0.68(0.35-1.22)$ & $1.00(0.58-1.39)$ & 0.001 \\
Nonheme iron & $9.97(6.59-13.54)$ & $12.93(8.80-17.91)$ & 0.001 \\
Total iron & $10.95(7.34-14.97)$ & $14.04(9.35-19.55)$ & 0.009 \\
Heme iron bioavailability & $0.16(0.08-0.28)$ & $0.23(0.13-0.32)$ & 0.001 \\
Nonheme iron bioavailability & $0.78(0.51-1.08)$ & $1.03(0.69-1.43)$ & 0.015 \\
Vitamin C & $107.16(43.86-203.69)$ & $64.59(27.80-132.13)$ & 0.009 \\
Meats & $87.83(42.68-162.04)$ & $119.0(69.75-189.33)$ & \\
\hline
\end{tabular}

Note: Dietary variables expressed as medians and 25 and 75 percentiles; $p$ according to the Mann-Whitney test.

Table 3. Difference between the apparent iron intakes of members of different age groups of sugarcane harvesters' families. Gameleira (PE), Brazil, 2007.

\begin{tabular}{|c|c|c|c|c|c|}
\hline Age group & $\mathrm{Z}_{1}$ & $z_{2}$ & $\left(Z_{1}-Z_{2}\right) \pm S D$ & $t$ test & $p$ value \\
\hline Men ( $\geq 15$ years $)^{1}$ & 3.15 & 1.55 & $1.60 \pm 1.72$ & 6.32 & $<0.001$ \\
\hline \multicolumn{6}{|l|}{ Women $(\geq 15 \text { years })^{2}$} \\
\hline Men ( $\geq 15$ years) ${ }^{1}$ & 3.17 & 0.77 & $2.40 \pm 1.72$ & 7.24 & $<0.001$ \\
\hline \multicolumn{6}{|l|}{ Children $(<5 \text { years })^{2}$} \\
\hline Men $(\geq 15 \text { years })^{1}$ & 3.11 & 1.29 & $1.82 \pm 1.65$ & 6.33 & $<0.001$ \\
\hline \multicolumn{6}{|l|}{ Children/Adolescents (5-14 years) ${ }^{2}$} \\
\hline Women $(\geq 15 \text { years })^{1}$ & 1.86 & 0.77 & $1.09 \pm 1.81$ & 3.13 & 0.02112 \\
\hline \multicolumn{6}{|l|}{ Children $(<5 \text { years })^{2}$} \\
\hline Women $(\geq 15 \text { years })^{1}$ & 1.35 & 1.30 & $0.05 \pm 1.65$ & 0.19 & 0.86254 \\
\hline \multicolumn{6}{|l|}{ Children/Adolescents (5-14 years) ${ }^{2}$} \\
\hline Children $(<5 \text { years })^{1}$ & 0.83 & 1.58 & $-0.75 \pm 0.83$ & -3.70 & 0.00201 \\
\hline Children/Adolescents (5-14 years) ${ }^{2}$ & & & & & \\
\hline
\end{tabular}

Note: ${ }^{1}$ Group one $Z_{1} ;{ }^{2}$ Group two $Z_{2}$.

Z: Mean apparent iron intake; SD: Standard Deviation.

intake difference of all study groups. The mean heme, nonheme, and total iron intakes increase gradually with age, peaking in men aged $\geq 15$ years.
Most children aged $<5$ years $(47.5 \%)$ consume diets with low iron bioavailability, and only $2.5 \%$ of these children consume diets with high iron bioavailability. Meanwhile, only a few 




Heme iron Nonheme iron Total iron

Figure 1. Mean dietary heme iron, nonheme iron, and total iron intakes of sugarcane harvesters' families by age group. Gameleira (PE), Brazil, 2007.

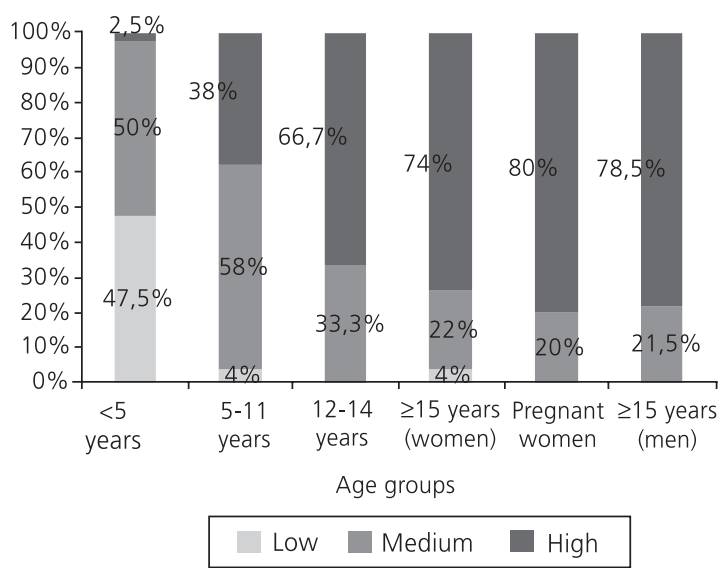

Figure 2. Iron bioavailability in the diets of sugarcane harvesters' families. Gameleira (PE), Brazil, 2007.

(4.0\%) children aged 5 to 11 years and women aged $\geq 15$ years consume diets with low iron bioavailability, and $38.0 \%$ of the said children consume diets with high iron bioavailability. None of the adolescents aged 12 to 14 years, pregnant women, and men aged $\geq 15$ years consume diets with low iron bioavailability (Figure 2).

\section{DISCUSSION}

The present study found high prevalences of anemia in members of sugarcane harvesters' families of all age groups from the municipality of Gameleira (PE), indicating a moderate public health problem in women $(38.8 \%)$ and men $(20.3 \%)$. However, the situation is severe in preschool children (aged $<5$ years), schoolchildren (aged 5 to 14 years), and pregnant women, with rates of $67.6 \%, 46.2 \%$, and $60 \%$, respectively. These rates are much higher than the mean global rates: $30.2 \%$ in women; $12.7 \%$ in men; $47.4 \%$ in preschool children; $25.4 \%$ in schoolchildren; and $41.8 \%$ in pregnant women 1 .

As the rates of iron-deficiency anemia found by the present study show, children aged $<5$ years are the most susceptible age group, with a rate similar to that found in Africa ${ }^{1}$ and higher than those found by other Brazilian studies for children of the same age group ${ }^{10-12}$.

The prevalence of anemia in children is relatively well studied. The Brazilian literature contains three systematic reviews on the prevalence of anemia and its determinants ${ }^{13-15}$. Fifty-three percent of the children aged $<5$ years are anemic ${ }^{13}$. However, Vieira \& Ferreira ${ }^{15}$ point out different mean prevalences of anemia in children according to some epidemiologic landscapes: population-based studies (40.1\%), schools or daycare centers (52.0\%), health services (60.2\%), and socioeconomically vulnerable populations (63.5\%). These authors also emphasize that in socioeconomically vulnerable populations, which include indigenous communities, rural settlements, slums, and Pastoral da Criança (Children's Pastoral) users, anemia is concerning because the children in these populations are almost three times more likely to be anemic than those in the general population. Children of sugarcane harvesters' families from Gameleira (PE) present a rate of anemia similar to those found in those vulnerable populations, hence evidencing a socioeconomic context of vulnerability to this condition.

The rate of anemia in women (38.8\%) found by the present study was higher than that for women of childbearing age of the state of Pernambuco (16.4\%) $)^{16}$ and of Brazil (29.4\%), according to the Pesquisa Nacional de Demografia e Saúde da Criança e da Mulher (PNDS, National 
Child and Woman Demographic and Health Survey) $)^{12}$. However, the PNDS of the Brazilian Northeast region found a prevalence of anemia in women of $39.1 \%$, similar to that of the present study.

Studies of anemia in pregnant women have found great variations in the prevalences of anemia that stem mainly from different socioeconomic contexts, gestational week, and age ${ }^{17-19}$. Since the number of pregnant women in the study sample is small, it is not possible to make comparisons.

There is literature consensus that children aged $<5$ years and pregnant women are the most vulnerable groups to nutritional deficiencies, especially iron-deficiency anemia, because of their higher energy and nutritional requirements ${ }^{1}$. In infants, there is also the influence of the exhaustion of the iron reserves between the fourth and sixth months of life, usually accompanied by early weaning and incorrect supplementary feeding ${ }^{5,9}$. Therefore, special attention should be given to the diet of these groups, and proper food intake should be encouraged by other family members, but what has been found by the present study is that these groups have the worst apparent iron intake adequacy and in the case of children, a high exposure to diets with low iron bioavailability.

There are only a few studies on the prevalence of anemia in other population groups ${ }^{20-22}$. Studies of anemia in children and adolescents aged 6 to 18 years enrolled in public schools found prevalences of $3.6 \%$ in 2005 in Recife (PE) to 39.3\% in 2008 in Maringá (PR) ${ }^{21,22 .}$ A study done in Pelotas (RS) found a prevalence of anemia in adults of $20.6 \%{ }^{20}$.

Serum hemoglobin is the most sensitive and widely used indicator of iron-deficiency anemia in a population. Its determination is inexpensive and the estimates are appropriate. The means found for the study sample are higher than the cut-off points provided by the $\mathrm{WHO}^{1}$, except for children aged $<5$ years and adolescents aged 12 to 14 years whose means are closer to the respective cut-off points. Mild anemia is the most prevalent in all age groups (results not shown). However, this fact cannot be underestimated since the presence of iron-deficiency anemia is a late stage of severe iron deficiency, leading to functional impairments ${ }^{7}$.

Iron is found in foods in the form of heme and nonheme, and both have specific absorption percentages. The absorption of nonheme iron depends on intrinsic dietary factors, such as ascorbic acid and meats in general $6,23,24$.

Vitamin C keeps iron in the ferrous state and forms a more soluble compound, the chelate iron ascorbate ${ }^{23}$. In meats, some amino acids such as cysteine, histidine, and lysine, and some peptides affect iron absorption because these free amino acids in the intestine form soluble chelates with nonheme iron, increasing its bioavailability ${ }^{24}$. However, vitamin $\mathrm{C}$ only promotes iron absorption when consumed together with dietary iron sources ${ }^{2,9}$.

Therefore, the intake of meats and vitamin C is very important for this population since most of the iron it consumes is nonheme, present in foods of plant origin such as legumes, tubers, and grains. Beans, a food item considered part of a healthy diet, was the main dietary source of nonheme iron for all study age groups (results not shown). The Pesquisa de Orçamentos Familiares (POF, Household Budget Survey) of 2008/ $2009^{25}$ found that adults with lower income have a high intake of beans and the intake is even higher in rural areas. However, bean intake has been decreasing in Brazil.

The low intake of foods high in heme iron may be explained by the poor diet of this population, where meats are consumed habitually by less than $70 \%$ of the study population and by less than $40 \%$ of the study children aged $<5$ years (results not shown). These foods high in heme iron are the ones that increase food expenses the most ${ }^{25}$. Hence, the high local prices of these items compared with other food items impair access to them and their acquisition, resulting in inadequate intake. Heme iron intake is important for the 
prevention of iron-deficiency anemia because it is well absorbed by the body (15\% to $35 \%$ ) and nearly not affected by other food constituents ${ }^{6}$. Additionally, children aged $<5$ years are less likely to consume a diet with high iron bioavailability because they consume fewer foods with high iron content than other family members.

The importance of consuming foods high in iron for the occurrence of anemia in the study population was also evidenced by the direct moderate correlation between the hemoglobin level and dietary iron intake, including its bioavailability (results not shown). Such associations are corroborated by Ai-Assaf ${ }^{26}$ and Rodríguez et al. ${ }^{27}$, reinforcing the proposition that inadequate iron intake and low bioavailability are the main determinants of anemia and confirming the validity of food surveys for detecting individuals at risk of anemia.

Although families have access to the same dietary sources of iron, the distribution of these foods within the family is unequal since the different iron requirement of each family member is not met, especially the requirements of women and children. This fact is evident when we compare the apparent iron intake of different age groups, noting a significant difference regarding the adequacy of men's intake as opposed to the adequacy of women's, children's, and adolescents' intakes. Women and schoolchildren have similarly inadequate intakes. Between preschool children and schoolchildren, the former are less likely to meet their iron requirement. Therefore, in addition to the physiological factors that place children and women at risk of anemia, there are still issues of food distribution within the family that prevent meeting the nutritional requirements of some groups.

Romanelli ${ }^{28}$ states that men are favored in this issue because women tend to leave the best part of the food preparations to their spouses when they take their meals to work. Moreover, discrimination within the family favoring men is also possibly due to the fact that they are the main providers ${ }^{29}$. Sudo et al. ${ }^{30}$ and Andrieu \& Caillavet ${ }^{31}$ also claim that adult males and male partners are favored in their iron intake requirements in detriment of other family members.

One of the limitations of this study is the small number of families, which resulted in a small number of individuals of certain groups. This was solved by combining some groups (children aged 5 to 11 years and adolescents aged 12 to 14 years) when analyzing the differences between their Z-scores. Another limitation regards not determining individual iron reserves, such as ferritin, to better estimate iron absorption. Iron absorption inhibitors present in foods of plant origin were also not considered.

It is important to point out that in the northeastern Zona da Mata where the municipality of Gameleira (PE) is located, the dominant presence of sugarcane monoculture opens a small and temporary space for subsistence agriculture in marginal areas not appropriate for sugarcane. Hence, given the economic structure of inadequate dynamism and small product diversity, salaried sugarcane harvesters' families living in this region have little access to food diversity, contributing even more to their nutrition disorders. This situation aggravates between sugarcane harvests, when family income decreases dramatically and these families survive, in most cases, with benefits provided by welfare programs and loans from relatives, friends, and retired family members ${ }^{4}$.

In summary, given the high prevalence of anemia and the inadequate intake of high-iron foods among sugarcane harvesters' families from the Brazilian Northeast, especially among children and women, there is an immediate need of adding nutritional surveillance to the permanent dietary, nutritional, and health care provided to this population in order to control and monitor this nutritional deficiency and implement effective food and nutrition security strategies.

\section{CONTRIBUTORS}

DS CAVALCANTI and MM OSÓRIO helped to conceive the study, analyze and interpret the data, write 
and review the manuscript. PN VASCONCELOS helped to write and review the manuscript. VM MUNIZ and NF SANTOS helped to analyze the data, write and review the manuscript.

\section{REFERE N CES}

1. World Health Organization. Worldwide prevalence of anaemia 1993-2005: WHO Global Database on Anaemia. Geneva: WHO; 2008.

2. Borges CQ, Silva RC, Assis AMO, Pinto EJ, Fiaccone $\mathrm{RL}$, Pinheiro SMC. Fatores associados à anemia em crianças e adolescentes de escolas públicas de Salvador, Bahia, Brasil. Cad Saúde Pública. 2009; 25(4):877-88. doi: 10.1590/S0102-311X200900 0400019

3. Kepple AW, Segall-Corrêa AM. Conceituando e medindo segurança alimentar e nutricional. Ciênc Saúde Colet. 2011; 16(1):187-99. doi: 10.1590/ S1413-81232011000100022

4. Campos LHR, Raposo I, Maia A. Empregabilidade do cortador de cana-de-açúcar da zona da mata pernambucana no período de entressafra. Rev Econ Nordeste. 2007 [acesso 2012 out 14]; 38(3):329-42. Disponível em: <http://www.bnb.gov.br/projweb ren/exec/artigoRenPDF.aspx?cd_artigo_ren= 1013>.

5. Oliveira MAA, Osório MM, Raposo MCF. Concentração de hemoglobina e anemia em crianças no Estado de Pernambuco, Brasil: fatores sócioeconômicos e de consumo alimentar associados. Cad Saúde Pública. 2006; 22(10):2169-78. doi: 10.1590/S0102 311X2006001000023

6. Monsen ER, Balintfy JL. Calculating dietary iron bioavailability: Refinement and computerization. J Am Diet Assoc. 1982; 80(4):307-11.

7. Monsen ER, Hallberg L, Layrisse M, Hegsted DM, Cook JD, Mertz W, et al. Estimation of available dietary iron. Am J Clin Nutr. 1978; 31(1):134-41.

8. Vitolo MR, Bortolini GA. Biodisponibilidade do ferro como fator de proteção contra anemia entre crianças de 12 a 16 meses. J Pediatr. 2007; 83(1):33-8. doi: 10.1590/S0021-75572007000100007

9. Institute of Medicine. Dietary reference intakes: The essential guide to nutrient requirements. Washington (DC): National Academies Press; 2006.

10. Oliveira JS, Lira PIC, Osório MM, Sequeira LAS, Costa EC, Gonçalves FCLSP, et al. Anemia, hipovitaminose A e insegurança alimentar em crianças de municípios de baixo índice de desenvolvimento humano do Nordeste do Brasil. Rev Bras Epidemiol. 2010; 13(4):651-64. doi: 10.1590/S1 415-790X2010000400010
11. Leal LP, Batista Filho M, Lira PIC, Figueiroa JN, Osório MM. Prevalência da anemia e fatores associados em crianças de seis a 59 meses de Pernambuco. Rev Saúde Pública. 2011; 45(3):457-66. doi: 10.1590/S0034-89102011000300003

12. Brasil. Ministério da Saúde. Pesquisa Nacional de Demografia e Saúde da Criança e da Mulher - PNDS 2006: dimensões do processo reprodutivo e da saúde da criança. Brasília; 2009. Série G. Estatística e Informação em Saúde.

13. Jordão RE, Bernardi JLD, Filho AAB. Prevalência de anemia ferropriva no Brasil: uma revisão sistemática. Rev Paul Pediatr. 2009; 27(1):90-8. doi: 10.1590/ S0103 05822009000100014

14. Leal LP, Osório MM. Fatores associados à ocorrência de anemia em crianças menores de seis anos: uma revisão sistemática dos estudos populacionais. Rev Bras Saúde Matern Infant. 2010; 10(4):417-39. doi: 10.1590/S1519-38292010000400003

15. Vieira RCS, Ferreira HS. Prevalência de anemia em crianças brasileiras, segundo diferentes cenários epidemiológicos. Rev Nutr. 2010; 23(3):433-44. doi: 10.1590/S1415-52732010000300011

16. Migliolo TC, Brito AM, Lira PIC, Figueroa JN, Batista Filho M. Anemia no binômio mãe-filho no estado de Pernambuco, Brasil. Cad Saúde Pública. 2010; 26(9):1807-20. doi: 10.1590/S0102-311X20100 00900014

17. Ferreira HS, Moura FA, Cabral Júnior CR. Prevalência e fatores associados à anemia em gestantes da região semi-árida do Estado de Alagoas. Rev Bras Ginecol Obstet. 2008; 30(9):445-51. doi: 10.1590/ S0100-72032008000900004

18. Côrtes MH, Vasconcelos IAL, Coitinho DC. Prevalência de anemia ferropriva em gestantes brasileiras: uma revisão dos últimos 40 anos. Rev Nutr. 2009; 22(3):409-18. doi: 10.1590/S1415-52732009000 300011

19. Fujimori E, Sato APS, Szarfarc SC, Veiga GV, Oliveira VA, Colli $C$, et al. Anemia em gestantes brasileiras antes e após a fortificação das farinhas com ferro. Rev Saúde Pública. 2011; 45(6):1027-35. doi: 10.1590/S0034-89102011005000078

20. Santos IS, Minten GC, Valle NCJ, Tuerlinckx GC, Boccio J, Barrado DA, et al. Helicobacter pylori and anemia: A community-based cross-sectional study among adults in Southern Brazil. Cad Saúde Pública. 2009; 25(12):2653-60. doi: 10.1590/S0102-3 $11 \times 2009001200012$

21. Nishida FS, Uchimura TT, Szarfarc SC, Bossato TF, Carvalho NA, Uchimura NS. Prevalência de anemia em escolares de escolas públicas de Maringá-PR, 2008. Rev Eletr Enferm. 2010 [acesso 2012 dez 18]; 12(2):237-44. Disponível em: <http://www. 
revistas.ufg.br/index.php/fen/article/view/6430/ 6900 > doi: 10.5216/ree.v12i2.6430

22. Lemos MCC. Anemia em alunos de escolas públicas no Recife: um estudo de tendências temporais. Ciênc Saúde Colet. 2011; 16(10):3993-4000. doi: 10.1590/S1413-81232011001100004

23. Cook JD, Reddy MB. Effect of ascorbic acid intake on nonheme-iron absorption from a complete diet. Am J Clin Nutr. 2001; 73(1):93-8.

24. Storcksdieck S, Bonsmann G, Hurrell RF. Ironbinding properties, amino acid composition, and structure of muscle tissue peptides from in vitro digestion of different meat sources. J Food Sci. 2007; 72(1):S019-29. doi: 10.1111/j.1750-3841.2 006.00229.x

25. Instituto Brasileiro de Geografia e Estatística. Pesquisa de orçamentos familiares 2008-2009: análise do consumo alimentar pessoal no Brasil. Rio de Janeiro: IBGE; 2011 [acesso 2012 out 10]. Disponível: <http://www.ibge.gov.br/home/ estatistica/populacao/condicaodevida/pof/ 2008_2009_analise_consumo/pofanalise_2008_ 2009.pdf>

26. Ai-Assaf AH. Anemia and iron intake of adult Saudis in Riyadh City-Saudi Arabia. Pak J Nutr. 2007 [acesso 2012 dez 18]; 6(4):355-8. Disponível em: $<$ http://www.pjbs.org/pjnonline/fin708.pdf>.
27. Rodríguez SC, Hotz C, Rivera J. Bioavailable dietary iron is associated with hemoglobin concentration in Mexican preschool children. J Nutr. 2007; 137(10):2304-10.

28. Romanelli G. O significado da alimentação na família: uma visão antropológica. Medicina. 2006; 39(3):333-9.

29. Canesqui AM. Mudanças e permanências da prática alimentar cotidiana de famílias de trabalhadores. In: Canesqui AM, Garcia RWD. Antropologia e Nutrição: um diálogo possível. Rio de Janeiro: Fiocruz; 2005. Coleção Antropologia e Saúde.

30. Sudo N, Sekiyama M, Maharjan M, Ohtsuka R. Gender differences in dietary intake among adults of Hindu communities in lowland Nepal: Assessment of portion sizes and food consumption frequencies. Eur J Clin Nutr. 2006; 60(4):469-77. doi: 10.1038/sj.ejcn.1602339

31. Andrieu E, Caillavet F. Inégalités nutritionnelles au sein des ménages: la pauvreté joue-t-elle un rôle? Cah Nutr Diét. 2006; 41(2):75-85. doi: 10.1016/ S0007-9960(06)70611-3

Received on: 5/9/2013

Final version on: 12/18/2013

Approved on: 1/20/2014 
